\title{
TRAUMA HEALING PASCABENCANA PADA ANAK-ANAK KORBAN GEMPA BUMI MELALUI PELATIHAN DA SUMINAGASHI (MELUKIS DI ATAS AIR) DI DESA REMBUN, KECAMATAN DAMPIT KABUPATEN MALANG
}

\author{
Siti Sumarsilah, Anita Kurnia Rachman, Susandi \\ IKIP Budi Utomo \\ sumarsilah1957@gmail.com, Anita27rachman@gmail.com, Susandi.ikipbudiutomo@gmail.com
}

\begin{abstract}
Community service carried out by Lecturer of Indonesian Language and Literature Education Study Program, IKIP Budi Utomo aims to help children affected by the earthquake to reduce trauma healing through playing activities and painting on water. The implementation method used in this activity is the method of playing and painting together on water (da suminagashi). Trauma Healing is a situation where children feel fear, anxiety, and fear due to events, accidents, natural disasters that have been experienced. This activity was carried out for three days and in collaboration with the Omdobara Command Post in Rembun Village, Dampit District, Malang Regency. This service activity is also assisted by four coordinators at the Omdobara Command Post who are used to interacting with children every day. The results of this activity, which can help parents and children in reducing the trauma caused by the earthquake that occurred a few months ago. Another result is that children can play and learn to paint on water together so that children can be happy again.
\end{abstract}

Keywords: trauma healing, mentoring, da suminaghasi

\section{ANALISIS SITUASI}

Dampit menjadi bagian dari kecamatan yang ada di Kabupaten Malang. Kecamatan Dampit terletak pada 112,4271 BT - 112,4849 BT dan 8,1806 LS - 8,0968 LS. Kecamatan Dampit, delapan desa yang berada di lereng dan empat desa yang secara topografi masuk pada desa yang tergolong bukit dan daerah dataran. Dampit memiliki luas wilayah $135,31 \mathrm{~km}^{2}$. Hal ini dapat diartikan 4,55\% dari luas Kabupaten Malang. Perbukitan mendominasi wilayah Kecamatan Dampi. Panorama yang indah menjadi salah satu daya Tarik Kecamatan Dampit. Namun kondisi ini belum dimanfaatkan secara optimal, sehingga dapat membantu perekonomian masyarakat. (Hadi, 2014).

Kecamatan Dampit memiliki 12 desa. Salah satu desa yang terdapat di Kecamatan Dampit, yaitu Desa Rembun. Desa Rembun merupakan daerah perbukitan dan berada di Kabupaten Malang selatan (Hadi, 2014). Batas Desa Rembun sebelah utara dengan Desa Pojok Kecamatan Wajak. Sebelah selatan dengan Desa Kali Genteng Kecamatan Sumber Manjing. Sebelah timur dengan Desa Majang Tengah Kecamatan Tirtoyudo. Sebelah barat dengan Desa Gedog Wetan Kecamatan Turen. Luas wilayah yang dihuni, yaitu 22 ha dengan area sawah 141.43 ha dan kebun 44 ha. Luas kuburan 4.250 ha, luas pekarangan 20 ha, 1 taman 0,100 ha, dan perkantoran 4000 ha.

Pendidikan masyarakat di Desa Rembun tergolong tinggi. Masyarakat banyak menyekolahkan anaknya pada pendidikan formal dan pendidikan non formal. Sekolah di daerah ini dari tingkat dasar hingga tingkat atas. Penduduk usia 10 tahuh ke atas bebas dari buta huruf. Penduduk yang tidak tamat SD/sederajat 130 orang. Penduduk yang tamat SD/sederajat 585 orang. Penduduk yang tamat SLTP/sederajat 495 orang, penduduk yang tamat SLTA/sederajat 485 orang. Penduduk tamat D-1 18 orang. Penduduk tamat D-2 42 orang. Penduduk tamat D-3 36 orang. Peta Kecamatan Rembun dapat dilihat pada gambar 1 berikut. 


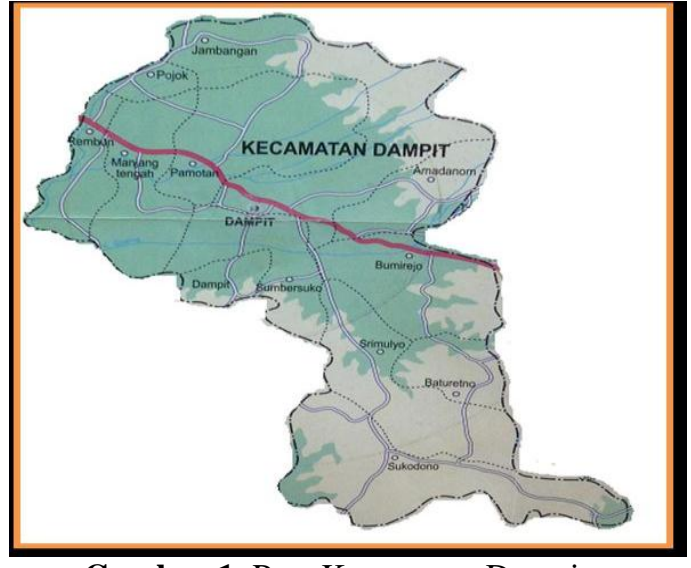

Gambar 1. Peta Kecamatan Dampit

Kondisi kehidupan masyarakata di Desa Rembun sedikit terganggu setelah terjadi gempa bumi yang terjadi di Malang Selatan beberapa bulan lalu. Gempa bumi yang terjadi dengan kekuatan magnitudo 6,1 terjadi Sabtu, 10 April 2021. Gempa bumi ini telah merusak beberapa rumah di Desa Rembun, Kecamatan Dampit, Kabupaten Malang. Kerusakan terjadi hampir satu desa dan menyebabkan dinding rumah warga retak dan mengalami kerusakan barat. Kerusakan ini terjadi pada tembok dan platform yang ambruk dan menimpa perabot rumah warga. Gempa bumi ini terjadi pukul 14:00:15 WIB berlokasi $90 \mathrm{~km}$ sebelah barat daya Kabupaten Malang, dengan kedalaman 25 $\mathrm{km}$ dan tidak berpotensi tsunami.

Dampak pascabencana gempa bumi tidak hanya menimbulkan kerusakan rumahrumah warga. Namun juga membuat anakanak mengalami ketakutan dan kecemasan. Anak-anak korban gempa bumi yang rumahnya retak dan hancur mengalami trauma karena merasa ketakutan akan terjadi gempa lagi. Akibatnya anak-anak menghabiskan waktu bermain di tempattempat yang disediakan sementara sampai rumah dan tempat tinggal mereka pulih kembali. Hal ini tentu akan berdampak bagi psikologi mereka selanjutnya.

Berdasarkan latar belakang di atas, Pengabdian Kepada Masyarakat yang dilakukan Dosen Prodi Pendidikan Bahasa dan Sastra Indonesia, IKIP Budi Utomo ini ditujukan membantu anak-anak dalam menyembuhkan trauma pascabencana gempa bumi dengan kegitan positif, yaitu melukis di atas air atau disebut $D a$ Suminagashi. Kagiatan ini dilaksanakan di Posko Omdobara di Desa Rembung menjadi tempat anak-anak bermain dan belajar bersama pascabencana gemba bumi. Maka pengabdian ini mengambil judul Trauma Healing Pascabencana Pada Anak-Anak Korban Gempa Bumi Melalui Pelatihan Da Suminagashi (Melukis Di Atas Air) di Desa Rembun, Kecamatan Dampit Kabupaten Malang. Kegiatan ini diharapkan sedikit banyak akan membantu dalam proses penyembuhan trauma yang dialami anakanak pascabencana gempa bumi.

\section{METODE PELAKSANAAN}

Kegitan pengabdian masyarakat yang dilaksanakan oleh tim pengabdian Prodi Pendidikan Bahasa dan Sastra Indonesia bekerjasama dengan Posko Omdobara yang di koordinatori oleh Ibu Rita Lianovita, S.Pd.

Kegiatan pertama dilaksanakan pada 10-12 November 2021, yaitu survei ke posko Omdobara untuk mengetahui kondisi awal dan bertemu dengan beberapa pendamping yang mendampingi anak-anak ketika belajar dan bermain di posko. Kegitan ini sekaligus meminta ijin untuk melaksanakan kegiatan pengabdian.

Kegiatan kedua dilaksanakan pada 17 November 2021, yaitu kegiatan sosialisasi trauma healing bagi anak-anak. Pada kegiatan ini tidak hanya dihadiri oleh anakanak korban bencana gempa tetapi juga dihadiri orang tua. Kegiatan ini berbentuk dialog dan diskusi bersama untuk mengatasi trauma yang dialami orang tua dan anakanak.

Kegiatan ketiga dilaksanakan pada 18 November 2021 berupa kegiatan pendampingan melukis di atas air. Kegiatan ini mengajarkan anak-anak untuk belajar melukis dengan media air, cat minyak, dan kanvas. Kanvas yang digunakan dalam 
bentuk tas, sehingga tas tersebut dapat dipakai anak-anak.

Kegitan keempat dilaksanakan 19 November 2021, yaitu kegiatan refleksi dan evaluasi terhadap kegiatan pengabdian. Kegiatan ini bermanfaat untuk orangtua dan anak-anak dalam mengurangi trauma yang diakibatkan bencana gempa.

Jadwa kegaitan Pengabdian Kepada Mayarakat berupa Trauma Healing Pascabencana Pada Anak-Anak Korban Gempa Bumi Melalui Pelatihan Da Suminagashi (Melukis Di Atas Air) di Desa Rembun, Kecamatan Dampit Kabupaten Malang dapat dilihat pada tabel 6.1 berikut.

Tabel 1 Jadwal Pengabdian

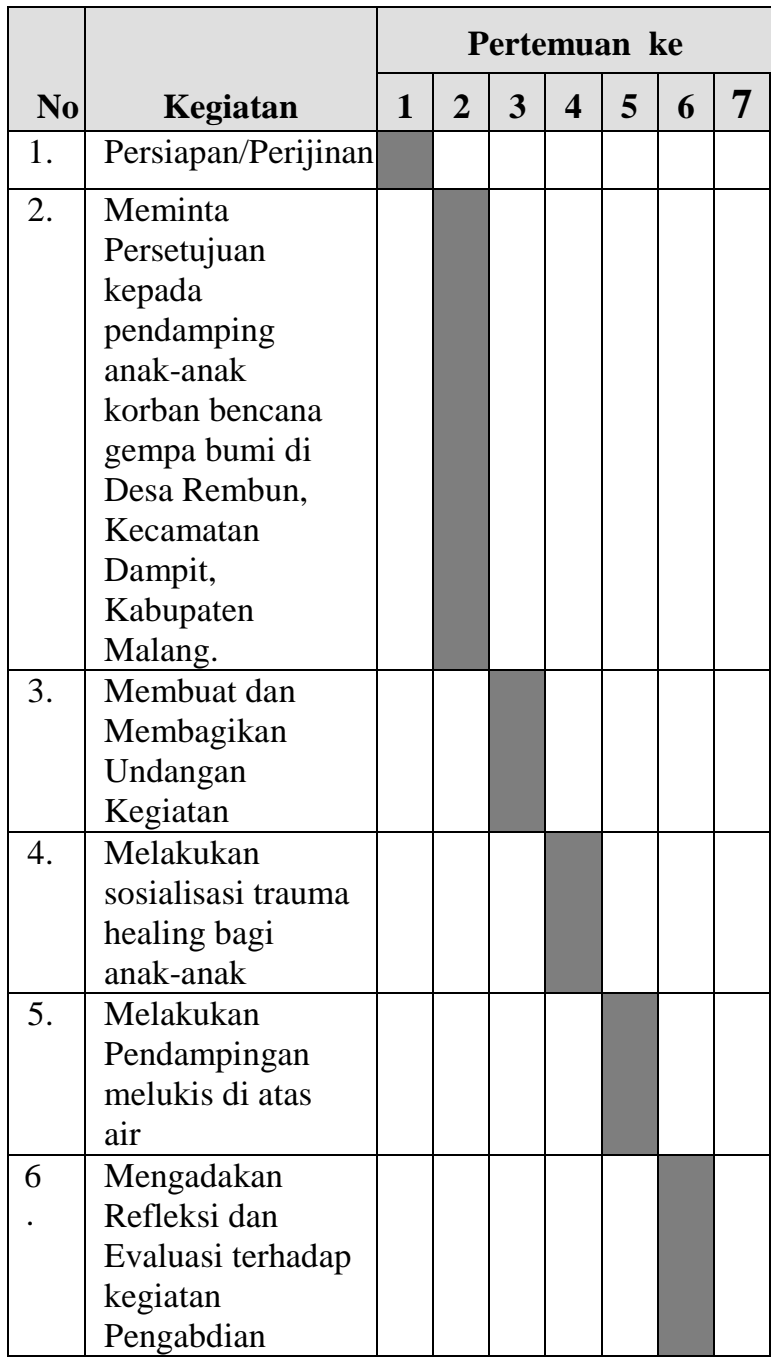

\section{HASIL DAN PEMBAHASAN}

Kondisi anak-anak korban gempa bumi di Desa Rembung perlu penangganan yang serius. Hal ini karena berhubungan dengan kondisi psikologi anak-anak akibat ketakutan, kecemasan, dan rasa tidak nyaman yang ditimbulkan pascabencana. Berikut hasil kegitan pengabdian yang dilaksanakan oleh tim pengabdian Prodi Pendidikan Bahasa dan Sastra Indonesia.

1) Trauma Healing Bagi Anak-Anak

Anak-anak korban pascabencana memerlukan perhatian untuk masalah psikologis (Kemdikbud, 2018). Masalah psikologis ini berupa Posttraumatic Stress Disorder (PTSD). Pengurangan trauma akibat bencana dapat dilakukan dengan trauma healing. Trauma merupakan respon emosional pada hal buruk dan tidak menyenangkan seperti kecelakaan, kejahatan maupun bencana alam. Kondisi ini disebut trauma. Keadaan ini berhubungan dengan kondisi psikologis. Esther Giller, Sidran Institute (2018) menyebutkan "A traumatic event or situation creates psychological trauma when it overwhelms the individual's ability to cope, and leave that person fearing death, annihilation, mutilation, or psychosis". Trauma psikologis dapat disebut pengalaman individu yang sedang merasa kewalahan secara emosi, kognitif, dan fisik serta ketidakmampuan mengatasi kondisinya terganggu. Trauma adalah kejadian emosional dan fisik karena mengakibatkan kerusakan substansial fisik dan psikologis dalam rentanga waktu yang relatif lama (Weaver, 2003).

Keadaan trauma menyebabkan kondisi emosional berkembang karena peristiwa menyedihkan, menyakitkan, menakutkan, mencemaskan dan menjengkelkan. Trauma berdasarkan kamus Psikologi, yaitu shock berupa fisik atau struktural juga mental berbentuk shock emosi. Hal ini mengakibatkan gangguan fungsi-fungsi mental (Drever, 1988). Healing dalam bahasa berarti penyembuhan (Shadily, 1992). Berdasarkan pengertian diatas, dapat

Siti Sumarsilah - Trauma Healing Pascabencana Pada Anak-AnakKorban Gempa Bumi Melalui Pelatihan Da Suminagashi (Melußis Di Atas Air) di Desa Rembun, Kecamatan Dampit Kabupaten Malang 
disimpulkan trauma healing adalah satu proses pemberian bantuan penyembuhan mengatasi gangguan psikologis meliputi kecemasan, panik, dan gangguan lainnya karena lemahnya ketahanan fungsi mental individu korban bencana alam. Salamor, dkk (2020) menyebutkan trauma healing merupakan accepting, yaitu tentang penerimaan. Trauma Healing merupakan kebutuhan utama bagi korban bencana. Terapi trauma healing membuat korban dapat berangsur pulih dari traumanya.

\section{2) Manfaat Bermain Bagi Anak-Anak Korban}

Bencana Gempa Bumi

Trauma healing untuk anak-anak dilakukan melalui permainan sebagai bentuk terapi. Bermain membuat anak-anak lupa apa yang pernah dirasakan dan dilihat. Terapi bermain sebagai intervensi trauma healing Play therapy sebuah terapi yang menangani anak pasca trauma bencana yang bertujuan menghibur dan mengatasi masalah melalui bermain (Dzulfaqori, 2017).

Play therapy mengalihkan fokus anak dari situasi mencekam. Bermain mempersiapkan mental anak dapat menerima situasi sekarang dan dapat bermakna kegiatan fisik berupa terapi (Nawangsih, 2014). Bermain yang dilakukan anak-anak mampu mengalihkan rasa trauma dan mendapat efek relaksasi berupa kesenangan permainan (Supartini, 2004).

\section{3) Melukis di Atas Air (Da Suminagashi)}

Suminagashi memiliki prinsip menitikan tinta ke permukaan air untuk membuat corak pada media kertas (paper marbling). Suminagashi merupakan seni tradisional dari Jepang. (Amanda dan Anas, 2019).

Kegiatan melukis di atas air bagi anak-anak korban gempa bumi dapat dilakukan sambil bermain. Anak-anak cenderung menyukai warna dan corat-coret dengan cat warna. Hal ini akan membuat anak terhibur dan sekaligus dapat membanti trauma healing. Teknik marbling pada suminagashi merupakan teknik melukis di atas air untuk menghasilkan marbleized (tekstur seperti marmer). Pola dari teknik mengapung di atas permukaan air biasa atau larutan kental. Selanjutnya dengan hati-hati dipindahkan ke penyerap, seperti kertas atau kain. (Ramugade, Warde, dan Sekar, 2014:1203).

Hasil kegiatan pengabdian kepada masyarakat yang dilaksanakan oleh tim pengabdian Prodi Pendidikan Bahasa dan Sastra Indonesia dapat dilihat pada foto-foto kegiatan berikut.

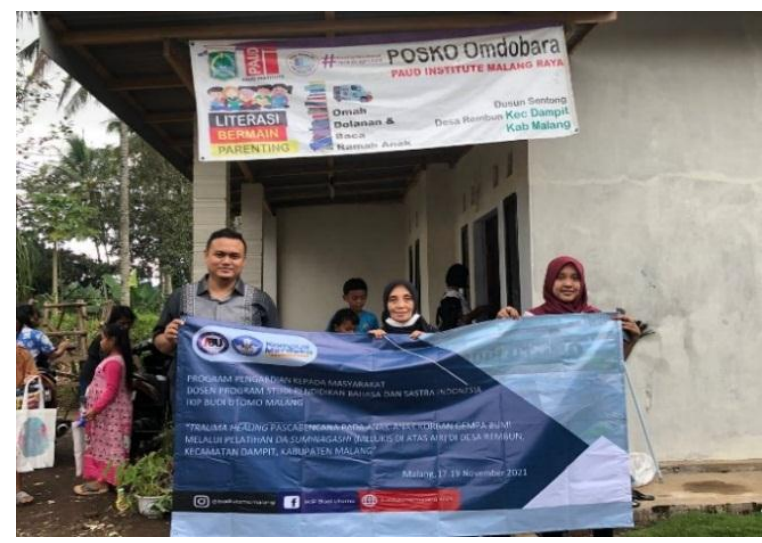

Gambar 1. Tim Pengabdian Dosen Prodi Pendidikan Bahasa dan Sastra Indonesia

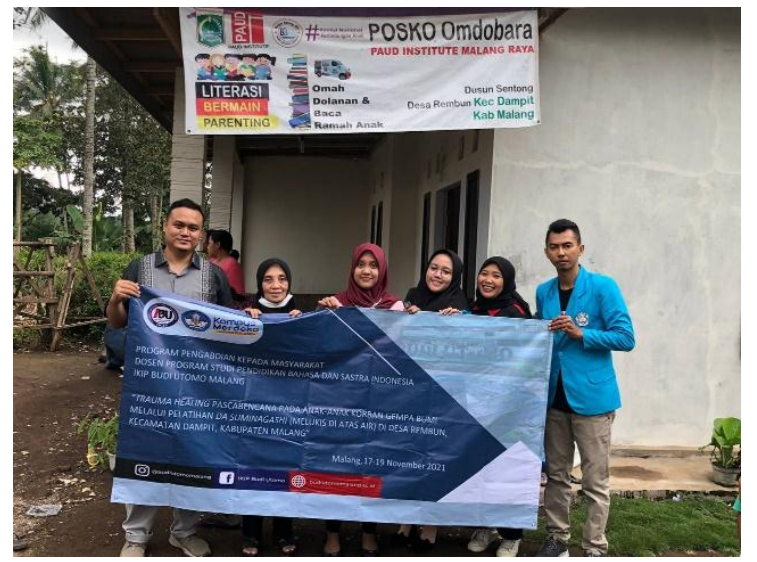

Gambar 2. Tim Pengabdian Dosen dan Mahasiswa Prodi Pendidikan Bahasa dan Sastra Indonesia 


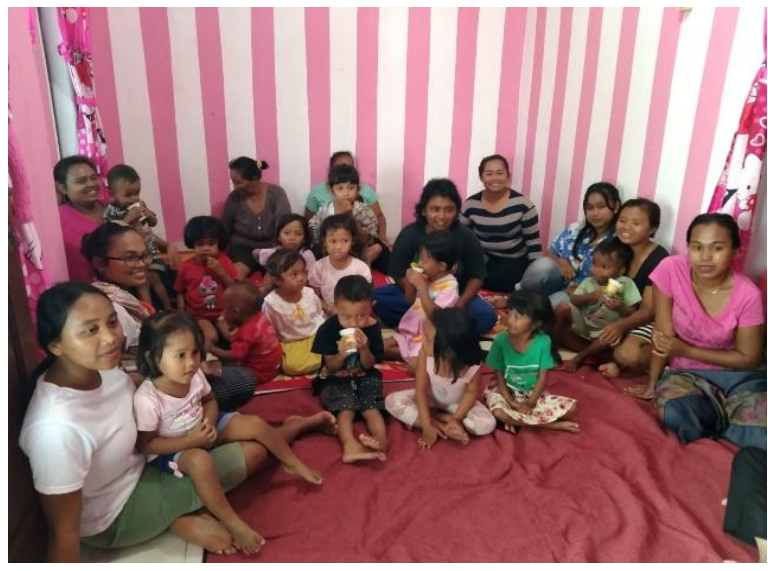

Gambar 3. Dialog dengan Anak-Anak dan Orangtua tentang Trauma Healing

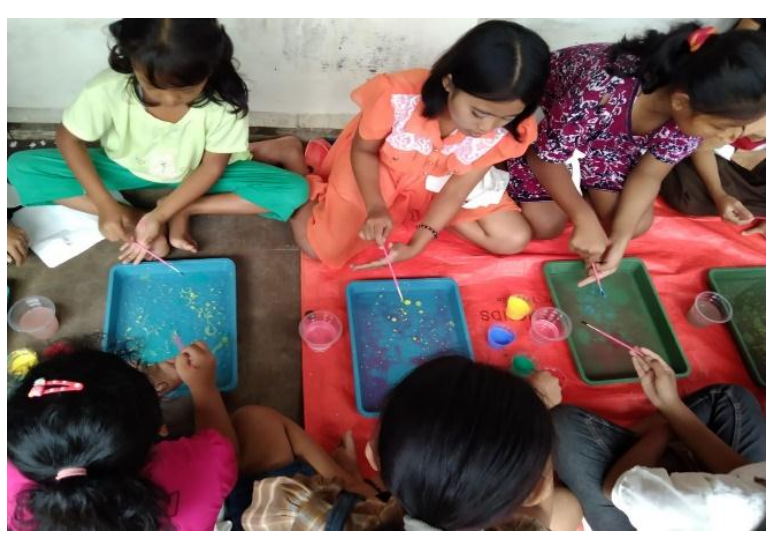

Gambar 5. Proses Anak-Anak Melukis di Atas Air
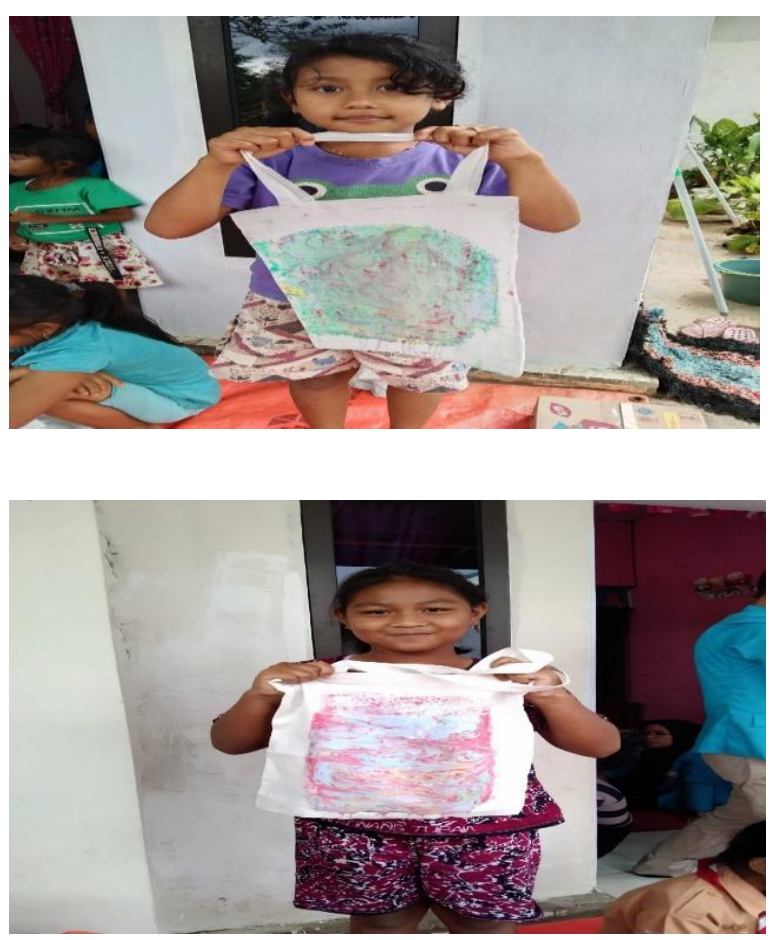

Gambar 6. Hasil Karya Anak-Anak Melukis di Atas Air
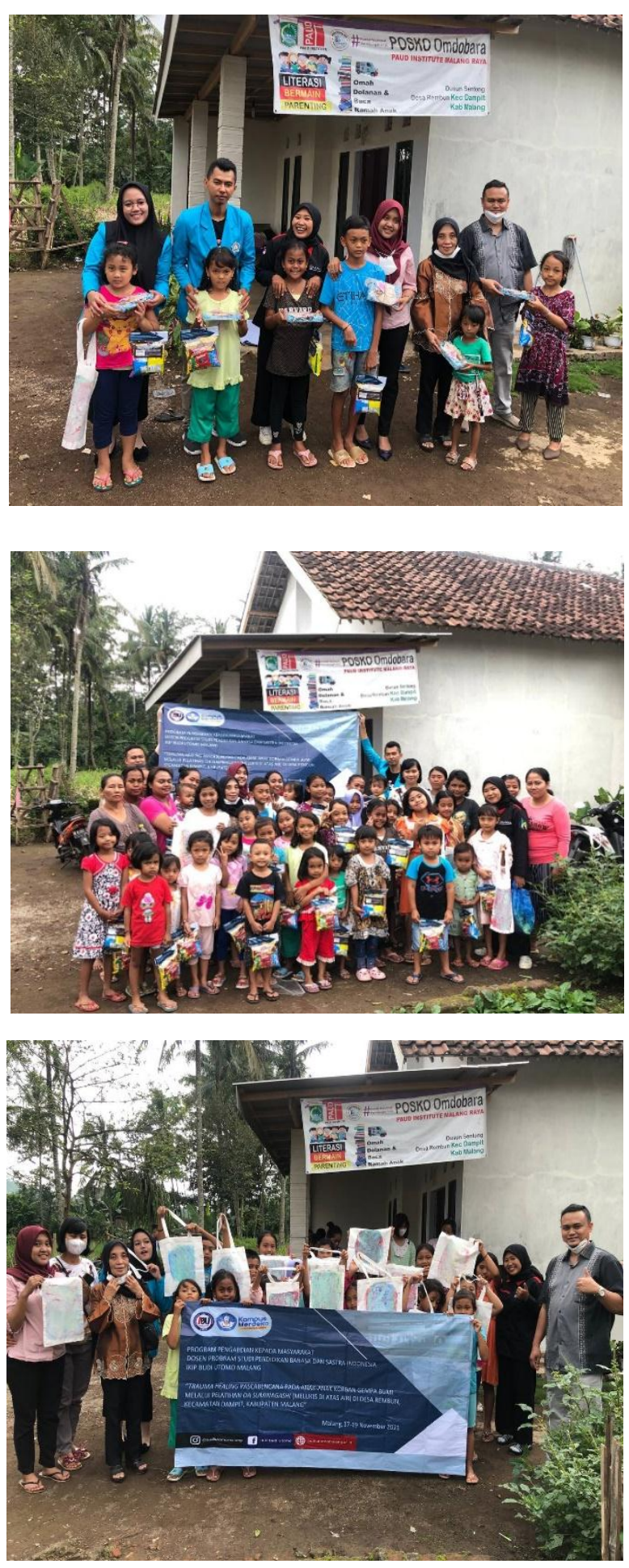

Gambar 7. Kebersamaan Tim Pengabdian, Koordinator, Anak-Anak, dan Orangtua

Siti Sumarsilah - Trauma Healing Pascabencana Pada Anak-Anak Korban Gempa Bumi Melalui Pelatihan Da Suminagashi (Melußis Di Atas Air) di Desa Rembun, Kecamatan Dampit Kabupaten Malang 


\section{KESIMPULAN}

Kegiatan Pengabdian Kepada Masyarakat yang dilakukan Dosen Prodi Pendidikan Bahasa dan Sastra Indonesia memiliki kesimpulan sebagai berikut. Kegiaatan Trauma Healing Pascabencana Pada Anak-Anak Korban Gempa Bumi Melalui Pelatihan Da Suminagashi (Melukis Di Atas Air) di Desa Rembun, Kecamatan Dampit Kabupaten Malang merupakan salah satu kegiatan dalam membantu anak-anak dan orangtua untuk menguarngi rasa trauma yang dirasakan akibat bencana gempa bumi. Kegiatan melukis di atas air yang dilakukan bersama anak-anak dapat membantu anakanak kembali ceria, belajar bersama, dan dapat melupakan rasa trauma yang dialami.

\section{DAFTAR RUJUKAN}

Amanda, Dinar dan Anas, Biranul. 2019. Eksplorasi Teknik Suminagashi Pada Produk Fashion. Jurnal Tingkat Sarjana bidang Senirupa dan desain. No 1.

Esther Giller. Sidran Institute. (2018). What Is Psychological Trauma? (Oniline), (https://www.sidran.org/resources/fors urvivors-and-loved-ones/whatispsychological-trauma/), diakses pada tanggal 12 Oktober 2020.

Kemdikbud. (2018). Modul Bimbingan Teknnis Pemulihan Trauma (Trauma Healing) Bagi Kepala Sekolah dan Pengawas Sekolah Pasca Bencana Kota Palu, Kab. Donggala, Kab. Sigi Provinsi Sulawesi Tengah. Kementerian Pendidikan dan Kebudayaan Direktorat Jenderal Guru dan Tenaga Kependidikan Direktorat Pembinaan Tenaga Kependidikan.

Nawangsih, Endah. (2014). Play Therapy Untuk Anak-anak Korban Bencana Alam Yang Mengalami Trauma (Post Traumatic Stress Disorder/PTSD).
Psympathic, Jurnal Ilmiah Psikologi, 1(2), 164-178.

Salamor, dkk. 2020. Trauma Healing Dan Edukasi Perlindungan Anak Pasca Gempa Bagi Anak-Anak Di Desa Waai. Communnity Development Journal. Vol.1, No. 3, Hal.317-321

Shadily, J. M. (1992). Kamus InggrisIndonesia an English-Indonesian Dictionary. Jakarta: Gramedia.

Supartini, Y. (2004). Buku Ajar Konsep DasarKeperawatan Anak. EGC.

Ramugade, S. H., U. S Warde. dan S. Nagaiyan. 2019. Azo dyes with ESIPT core for textile application sand DFT study. Jornal of Department of Dyestuff Technology, Instituteof Chemical Technology, Matunga, Mumbai, 400019, India. Hlm. 1-10.

Weaver, A. F. (2003). Counseling Survivors of Traumatic Events: A handbook for pastors and other helping professional. Nashville: Abingdon Press. 